\title{
Analysis of food habits of skate Rioraja agassizii (Elasmobranchii, Rajidae) from southern Brazil
}

\author{
N. S. Motta ${ }^{a *}$, N. Della-Fina ${ }^{a}$, C. C. A. Souza ${ }^{a}$, E. S. Rodrigues ${ }^{a}$ and A. F. Amorim ${ }^{a}$

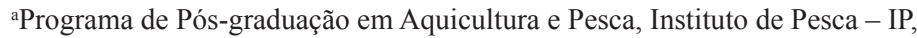 \\ Agência Paulista de Tecnologia dos Agronegócios - APTA, Secretaria de Agricultura e Abastecimento - SAA, \\ Av. Bartolomeu de Gusmão, 192, Ponta da Praia, CEP 11031-906, Santos, SP, Brazil \\ *e-mail: nathalia_sousam@yahoo.com.br
}

Received: October 14, 2014 - Accepted: January 14, 2015 - Distributed: May 31, 2016

(With 3 figures)

\begin{abstract}
Catches and exports of skate Rioraja agassizii place this species as "vulnerable to extinction" on the IUCN Red List; therefore, biological and ecological knowledge becomes an important instrument for its conservation control. This study described and quantified the diet composition of $R$. agassizii by means of stomach analysis contents in the periods 2005-2006 and 2012-2013. We analyzed and quantified stomach contents in terms of abundance $(\% \mathrm{~N})$, weight $(\% \mathrm{M})$, frequency of occurrence (\% FO), and index of relative importance (IRI). The results showed differences in the food rates between the periods. However, the groups of food items were the same: Teleostei fish, decapods, and mollusks. In 2005-2006, the diet consisted mainly of shrimp, however, in 2012-2013 it consisted of fish, followed by decapods, especially shrimps. The differences in diets may be attributed to shrimp abundance, which do not characterize a change in the eating habits in 2012-2013, because, in addition to fish, shrimps were also important food sources. The presence of a certain prey is more related to its availability rather than the feeding preference of skate. The amount of ingested items is associated to biological and environmental factors, so that further studies relating diet with capture area, seasonality, depth, and other factors should be conducted.
\end{abstract}

Keywords: diet, feeding ecology, feeding preference, prey, stomach content.

\section{Análise quantitativa dos hábitos alimentares da raia Rioraja agassizii (Elasmobranchii, Rajidae) do Sudeste e Sul do Brasil}

\section{Resumo}

A raia-santa, Rioraja agassizii é uma espécie endêmica da qual pouco se conhece sobre sua biologia e ecologia, o que a leva a ser classificada como "vulnerável a extinção". O objetivo foi identificar e quantificar a composição da dieta alimentar da $R$. agassizii através da análise do conteúdo estomacal de exemplares capturados nos períodos de 2005-2006 e 2012-2013. Foram analisados os conteúdos alimentares e quantificados em abundância (N\%), peso (M\%), frequência de ocorrência (FO\%) e índice de importância relativa (IRI) de cada item. Os resultados mostraram que em 2012-13 a dieta foi composta por peixes, seguido de decápodes, especialmente camarões, entretanto em 2005-06 foi composta basicamente por camarões. A diferença nas dietas não quer dizer que os hábitos alimentares mudaram, pois em 2012-13 além dos peixes, os camarões também foram classificados como maior importância alimentar. Considerando que a quantidade e variedade dos itens ingeridos está relacionada, principalmente, a fatores ambientais são necessários mais estudos que relacionem áreas de captura, sazonalidade e profundidade.

Palavras-chave: dieta, ecologia alimentar, preferencia alimentar, presa, conteúdo estomacal.

\section{Introduction}

Elasmobranchs present slow growth rate, late maturation, and low fecundity (Frisk, 2010). These factors, along with bycatch, can lead these organisms to a population decline, and the family Rajidae is one of the most vulnerable to exploitation (Dulvy and Reynolds, 2002).

The scenario of overfishing, lack of biological information, and catches led to overexploitation of various demersal elasmobranchs in Southeast Atlantic or South Occidental
Atlantic (Vooren and Klippel, 2005). Gaichas et al. (2005) claim for a proper management to protect the Rajidae family against locally depletion, especially when little is known about habits and structure of the population.

According to Ellis et al. (2010), research shows that some species of Rajidae feature very unequal distributions, which may make them locally prone to depletion. 
In Brazil, this family is represented by 11 genera and 26 species including the skate Rioraja agassizii (Müller and Henle, 1841), which occurs from the Espírito Santo State in Brazil to Argentina, more frequently on the coast of Rio de Janeiro and São Paulo States (Figueiredo, 1977). There is no conservation measure for the genera Atlantoraja and Rioraja (Hozbor et al., 2004; Massa et al., 2006; San Martín et al., 2007). The population of the genus Atlantoraja shows a trend to decline, however, for the genus Rioraja, this trend is still unknown (Kyne et al., 2007; IUCN, 2012). According to the IUCN, Atlantoraja castelnaui (Miranda-Ribeiro, 1907) is classified as “endangered at risk", while A. cyclophora (Regan, 1903), A. platana (Günther, 1880) and Rioraja agassizii are listed as "vulnerable" (IUCN, 2012).

Although endemic, the Rajidae family features a diversified diet, consuming different prey types such as fish, mollusks, and crustaceans (Ebert and Bizzarro, 2007). Because they inhabit higher trophic levels, they can compete directly with deep-sea fish (Link and Garrison, 2002). According to Wetherbee and Córtes (2004), to understand the energy flow between trophic levels, it is necessary to understand not only what elasmobranchs eat, but also characterize their digestion, energy processing, and nutrients in the prey consumed.

Food biology of sharks and skates have been studied to understand the natural history of a particular species, its ecological role in the ecosystem, the predation impact on preys with economic value such as the pink shrimp Farfantepenaeus brasiliensis (Latreille, 1817) and F. paulensis (Pérez-Farfante, 1967), and risks of extinction due to overexploitation (Wetherbee and Córtes, 2004; Aguiar and Valentin, 2010).

Many studies have investigated the diet and feeding habits of fish based on the analysis of stomach contents, but there is a lack of consistency in the results (Cortés, 1997). According to Vianna et al. (2000), studies on feeding habits are important to explain changes in aspects of fish growth, migration and reproduction.

Because of the constant catches of $R$. agassizii, especially bycatch, trawl fisheries, with high rejection on board, export increase, and mainly lack of information, the species was classified as "vulnerable". The knowledge of biological and ecological factors of this species is important for its effective management and conservation. This study described and quantified the diet composition of $R$. agassizii using stomach contents of specimens captured during 2005-2006 and 2012-2013 in southern Brazil.

\section{Material and Methods}

We analyzed stomach contents in 351 specimens of R. agassizii from March 2005 to April 2006 captured by fishing pair trawling, at depths ranging from 10 to $146 \mathrm{~m}$. Between June 2012 to September 2013, we captured 49 specimens by means of pink shrimp double trows, at depths of 25 to $70 \mathrm{~m}$. There was no specimen sampling during the closed shrimp season between March $1^{\text {st }}$ and May $31^{\text {st }}, 2013$ (Brasil, 2008) for the sampling period of 2012-2013. In both periods, the study site includes the coastal region from the states of Rio de Janeiro to Santa Catarina, southern Brazil (see Figure 1).

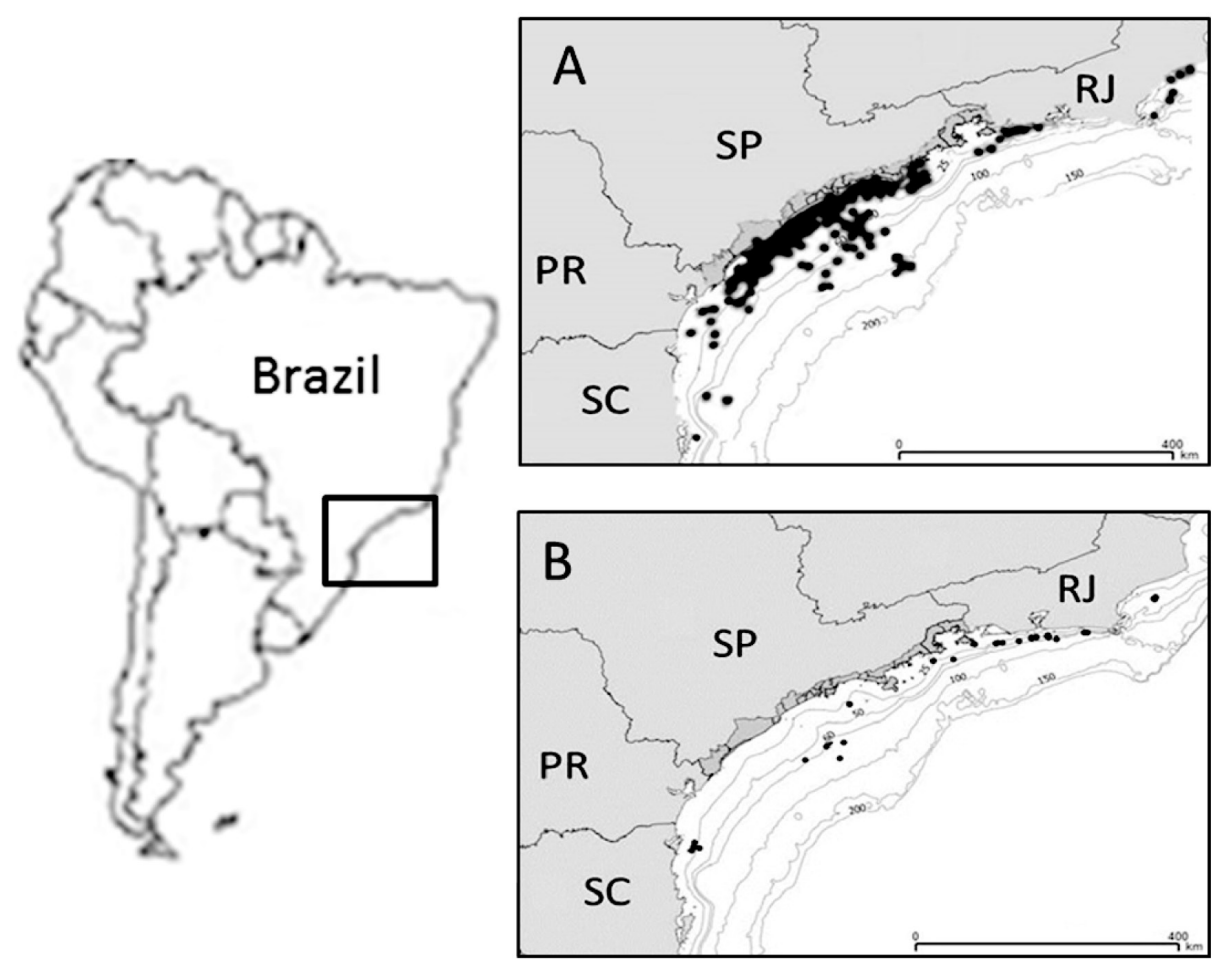

Figure 1. Capture area of skate Rioraja agassizii, captured in southern Brazil, in two periods, by pair trawl over the period of 2005-2006 (A) and by pink shrimp double trawls over the period of 2012-2013 (B). 
The specimens collected were identified, sexed, weighed (TW, kg) and the total length (TL, cm) was measured. After removal, their stomachs were weighed on a 1-g precision balance and classified at five levels in terms of repletion degree (RD): empty stomach = RD 0; almost empty (up to $25 \%$ ) $=\mathrm{RD}$ I; half full $(25-50 \%)=\mathrm{RD}$ II; almost full $(51-75 \%)$ $=$ RD III; and full stomach $(>75 \%)=$ RD IV (Soares et al., 1999; Dolgov, 2005).

The stomach contents were preserved in alcohol $70 \%$ for crustaceans, and in formalin $10 \%$ for fish. Afterwards, the contents were identified in taxonomic groups and weighed. The digestion degree of each prey was registered in three levels, as follows: undigested, with no signs of digestion $=1$; partially digested, but identifiable $=2$; and digested without identification with presence of otoliths, crystalline, and other appendages $=3$ (Soares and Apelbaum, 1994).

Each item of stomach contents was identified for the lowest possible taxon, according to identification guides (Figueiredo, 1977; Figueiredo and Menezes, 1978, 1980; Menezes and Figueiredo, 1985) and crustaceans (Melo, 1996, 1999; Pérez-Farfante and Kensley, 1997; Carpenter, 2002; Costa et al., 2003). For food analysis, abundance was represented by number of individuals (N\%) of each item. For biomass calculation, we used the weight (W\%) and calculated the frequency of occurrence $(\mathrm{FO} \%)$ of the food items in the stomach contents. We also estimated the index of relative importance (IRI), which establishes the importance of food items, using the formula of Schwingel and Castello (1994). For items of greater food importance, the IRI value was higher than 1,000 . For items of intermediate importance, the IRI ranged between 50-1,000, and those with lesser importance, the IRI values were smaller than 50 .

\section{Results}

\subsection{Samples from $2005-2006$}

Of the 351 specimens sampled between 2005-2006, 93.1\% were adults and only $6.9 \%$ juveniles. The sample contained 88 males with TL between $29.3-56.2 \mathrm{~cm}$ and 259 females with TL ranging from $26.5-58.2 \mathrm{~cm}$. Four specimens, one female and three males, did not provide TL measures, because their tails were damaged. Figure 2 a shows the TL distribution of the groups of sex of 347 specimens.

Only $5.2 \%$ of stomachs examined were empty and $94.8 \%$ contained some food. Most stomachs (35.9\%) showed RD I, followed by $20.8 \%$, RD II; $27 \%$, RD III; and $11.1 \%$, RD IV. Three major groups were identified, and shrimps (Penaeidae family) were the most important food source with IRI $=7,213.6$, followed by unidentified fish with $\mathrm{IRI}=649.7$ (as shown in Table 1). Among the shrimps, we identified Xiphopenaeus kroyeri (Heller, 1862), Farfantepenaeus paulensis, Rimapenaeus constrictus (Stimpson, 1874), and Litopenaeus schmitthi (Burkenroad, 1936).
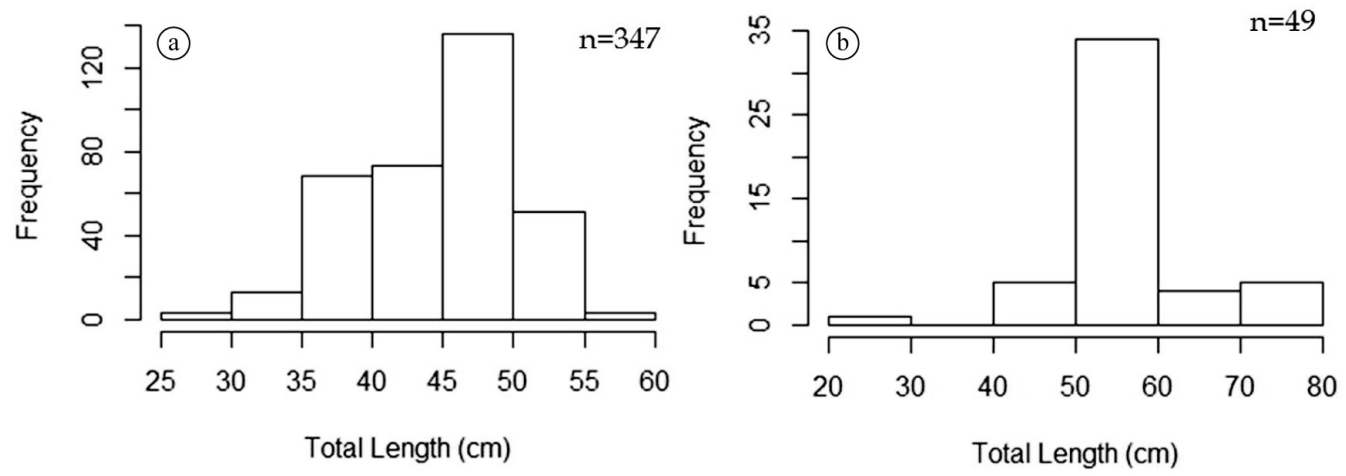

Figure 2. Histogram of total length (TL - cm) of skate Rioraja agassizii, collected during 2005-2006 (a) and 2012-20013 (b).

Table 1. Diet composition of skate Rioraja agassizii in the 2005-2006 period.

\begin{tabular}{lrrrrr}
\hline \multicolumn{1}{c}{ PREYS } & $\mathbf{\% N}$ & $\mathbf{\% M}$ & $\mathbf{\% F O}$ & \multicolumn{1}{c}{ IRI } & \%IRI \\
\hline TELEOSTEI & $\mathbf{3 . 2}$ & $\mathbf{4 3 . 5}$ & $\mathbf{1 4 . 7}$ & $\mathbf{6 8 6 . 5}$ & $\mathbf{7 . 2}$ \\
Bothidae (Bothus sp.) & 0.0 & 1.7 & 0.3 & 0.4 & - \\
Unidentified teleosts & 3.2 & 41.8 & 14.5 & 649.7 & - \\
CRUSTACEA & $\mathbf{9 2 . 9}$ & $\mathbf{4 4 . 0}$ & $\mathbf{6 5 . 0}$ & $\mathbf{8 , 9 0 1 . 1}$ & $\mathbf{9 2 . 8}$ \\
Penaeidae & 90.9 & 37.0 & 56.4 & $7,213.6$ & - \\
Brachyura & 0.1 & 0.3 & 0.5 & 0.2 & - \\
Portunidae & 0.9 & 2.5 & 4.7 & 15.8 & - \\
Squillidae & 0.0 & 0.1 & 0.3 & 0.0 & - \\
Unidentified crustaceans & 1.0 & 4.1 & 3.2 & 16.3 & - \\
MOLLUSCA_CEPHALOPODA & $\mathbf{0 . 1}$ & $\mathbf{0 . 5}$ & $\mathbf{0 . 5}$ & $\mathbf{0 . 3}$ & $<\mathbf{0 . 0 1}$ \\
Unidentified cephalopods & 0.1 & 0.5 & 0.5 & 0.3 & - \\
\hline
\end{tabular}

$\mathrm{N} \%$ - numerical percentage; $\mathrm{M} \%$ - mass percentage; $\mathrm{FO} \%$ - frequency of occurrence percentage; IRI - index of relative importance; IRI\% - percentage of IRI. Bold indicates the largest taxonomic group. 


\subsection{Samples from 2012-2013}

A number of 49 stomachs of 49 specimens of $R$. agassizii. Of the total sampled, two specimens were males with TL of 48.5 and $71.5 \mathrm{~cm}$. The TL of females ranged from $26.3-76.5 \mathrm{~cm}$ and all individuals were adults. Figure $2 \mathrm{~b}$ shows the TL histogram for grouped sex of the specimens sampled.

The results showed that $20.4 \%$ of the stomachs had RD 0; 36.7\%, RD I; 20.4\%, RD II; 8.2\%, RD III; and 14.3\%, RD IV. We identified three major food groups: fish, crustaceans, and mollusks, among which the teleostei group had the highest representativeness for food source according to the IRI, followed by decapods (as shown in Table 2). Most fish ( $\mathrm{N}=27.1 \%$ ) were classified as "unidentified fish" because of the advanced digestion state (grade 3) observing only with presence of otoliths, crystalline, and appendices.
The ost representative groups among the Teleostei fish were the Paralichthyidae family with $\mathrm{N}=8.2 \%$. In the group of decapods, the food item of greater importance was the shrimp with IRI $=746.8$, followed by the Achelous spinicarpus (Stimpson, 1871) with IRI $=364.9$.

\section{Discussion}

The food items were grouped into Teleostei (fish), Penaeidae (shrimp), Brachyura (crabs), Crustacea (Squillidae, Nephropidae) to facilitate the comparison of periods. We also observed a difference in the diet composition of $R$. agassizii in the 2005-2006 period, predominated by decapods, mainly shrimps of the family Penaeidae. Comparatively, in 2012-2013, the Teleostei fish showed the largest IRI and FO levels (see Figure 3). We also observed a difference between the

Table 2. Diet composition of skate Rioraja agassizii, in 2012 and 2013.

\begin{tabular}{lrrrrc}
\hline \multicolumn{1}{c}{ PREYS } & N\% & M\% & FO\% & IRI & IRI\% \\
\hline TELEOSTEI & $\mathbf{5 0 . 0}$ & $\mathbf{7 8 . 3}$ & $\mathbf{6 4 . 1}$ & $\mathbf{8 , 2 2 4 . 7}$ & $\mathbf{6 2 . 0}$ \\
Paralichthyidae & 8.2 & 14.8 & 15.4 & 354.9 & - \\
Ophidiidae (Raneya brasiliensis) & 0.8 & 1.6 & 2.6 & 6.1 & - \\
Anguiliforme & 2.2 & 6.4 & 7.7 & 66.6 & - \\
Mullidae (Mullus sp) & 1.5 & 10.7 & 2.6 & 31.3 & - \\
Triglidae (Prionotus sp) & 0.8 & 13.0 & 2.6 & 35.5 & - \\
Batrachoididae (Porichthys porosissimus) & 0.8 & 10.8 & 2.6 & 29.7 & - \\
Unidentified teleosts & 35.8 & 19.2 & 46.2 & $2,540.3$ & - \\
CRUSTACEA & $\mathbf{4 8 . 5}$ & $\mathbf{2 1 . 7}$ & $\mathbf{7 1 . 8}$ & $\mathbf{5 , 0 3 9 . 6}$ & $\mathbf{3 8 . 0}$ \\
Brachyura & 1.5 & 2.5 & 5.1 & 20.7 & - \\
Portunidae (Achelous spinicarpus) & 12.7 & 3.1 & 23.1 & 364.9 & - \\
Nephropidae (Metanephrops rubellus) & 3.0 & 5.1 & 10.3 & 83.3 & - \\
Penaeidae & 22.4 & 1.9 & 30.8 & 746.8 & - \\
Squillidae & 3.0 & 6.2 & 10.3 & 94.2 & - \\
Unidentified crustaceans & 6.0 & 4.5 & 15.4 & 160.7 & - \\
MOLLUSCA_GASTROPODA & $\mathbf{1 . 5}$ & $\mathbf{0 . 0 1}$ & $\mathbf{5 . 1}$ & $\mathbf{7 . 7}$ & $\mathbf{0 . 1}$ \\
Unidentified gastropods & 1.5 & 0.01 & 5.1 & 7.7 & - \\
\hline
\end{tabular}

$\mathrm{N} \%$ - numerical percentage; $\mathrm{M} \%$ - mass percentage; $\mathrm{FO} \%$ - frequency of occurrence percentage; IRI - index of relative importance; IRI\% - percentage of IRI. Bold letters indicates the largest taxonomic group.
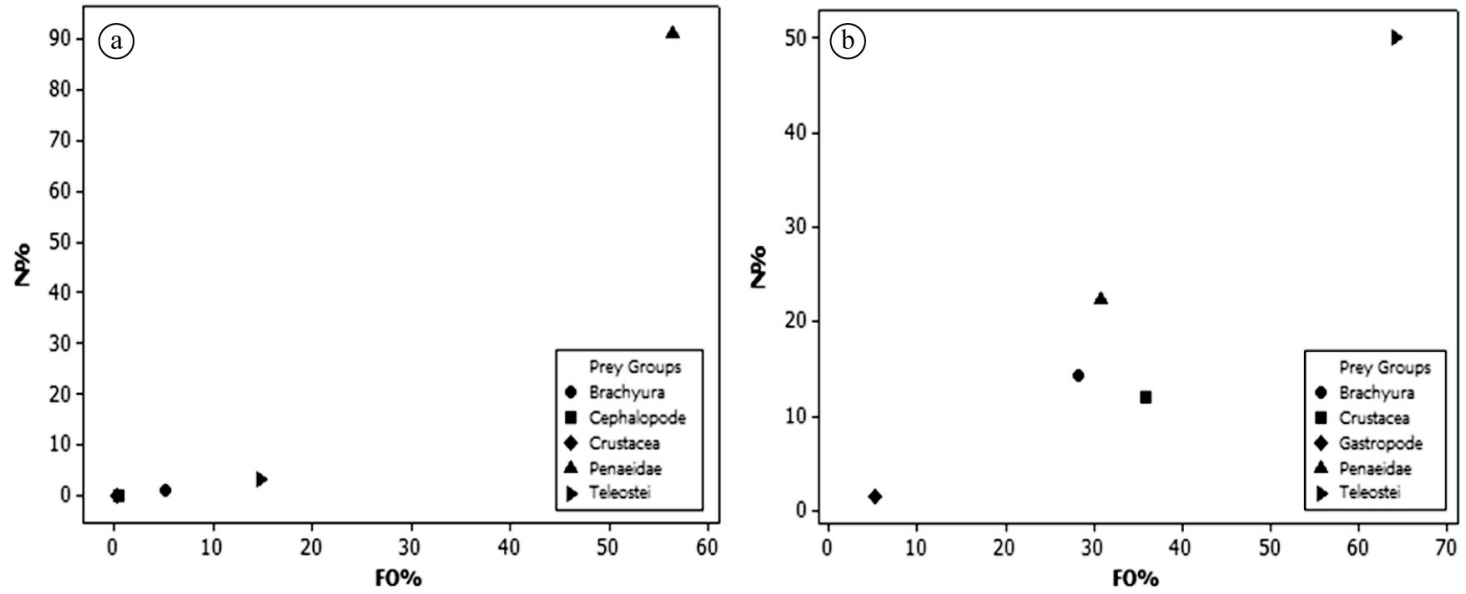

Figure 3. Graphical representation of the diet of skate Rioraja agassizii; (a) sampling of the 2005-2006 period; (b) sampling of 2012-2013 period. $\mathrm{N} \%=$ numerical percentage, $\mathrm{FO} \%=$ frequency of occurrence percentage. 
structure of the two populations, where in 2012-2013, the sample showed a smaller number of specimens, but with greater TL from 71.5 to $80 \mathrm{~cm}$ and predominance between $50-60 \mathrm{~cm}$. On the other hand, the sample of 2005-2006 showed the highest number of specimens, however, with predominance between $45-50 \mathrm{~cm}$ with maximum TL of $60 \mathrm{~cm}$. In both samples, all specimens were adults, which is confirmed in the literature (Oddone et al., 2007).

According to Muto et al. (2001), R. agassizii feeds on benthic items, mainly crustaceans such as shrimp and crabs, corroborated by the results obtained in the sample collected between 2005-2006. Food chronology of this skate was also studied by Soares et al. (1999), which concluded that its diets was also based on crustaceans and small teleostei fish. Soares et al. (1999) and Muto et al. (2001) performed his works on the coast of Ubatuba (Sao Paulo-SP State, Brazil) from scientific cruises, in a different sampling scenario from that conducted by commercial fishing boats.

The differences, comparing the two periods studied in this work with results obtained by other authors, were probably caused by different fishing gears (pair trawling and double trawls) that were used at different depths, sample size, time interval, in addition to the biotic and oceanographic factors.

The small number of specimens captured in the 2012-2013 sample may have been caused by ecological factors, environmental changes, modification of the fishing area, and fishing pressure from other vessels, since other studies show that this species is considered abundant in trawling.

Mazzoleni and Schwingel (1999) observed that the species $R$. agassizii, A. cyclophora, A. castelnaui, and $A$. platana, from catches of the fishing fleet landed in Itajaí (Santa Catarina State, Brazil), are classified as abundant in pair trawling. Muto et al. (2001) also consider R. agassizii and Psammobatis extenta (Garman, 1913) important in terms of abundance and biomass on the coast of Ubatuba (SP State, Brazil).

The fact that fish was the group with the highest IRI in 2012-2013 does not characterize a change in diet of $R$. agassizii, because decapods, mainly shrimps, were also identified in the stomach contents. For Schwingel and Assunção (2009), the Rajidae feature varied diet, while Muto et al. (2001) state that the diet of R. agassizii was based on shrimps (Caridae and Penaeidae) and small teleostei fish. According to Marion et al. (2011), the presence of crustaceans in the stomach contents of batoid elasmobranchs is relatively common, as found in Zapteryx brevirostris and other studies.

Barbini and Lucifora (2011) also studied feeding habits of $R$. agassizii, however, in the region between Uruguay and Argentina, and observed values similar to the IRI for teleostei fish and decapods, $34.4 \%$ and $33.9 \%$, respectively. The authors also observed that their results are different from results obtained by Soares et al. (1999) and Muto et al. (2001) on the coast of Ubatuba (SP State, Brazil). The results obtained by Barbini and Lucifora (2011) were similar to those found in the 2012-2013 sampling, with fish showing IRI values slightly higher than those for the group of decapods.

The presence (or absence) of a prey in the stomach of predator may be attributed to the availability (or not) in the environment or to the facility or difficulty of capture (Zavala-Camin, 1996). Seasonal and geographical differences found in food diets are more related to prey community and availability, which can change, for example, due to intense fishing activity (Muto et al., 2001; Wetherbee and Córtes, 2004; Ebert and Bizzarro, 2007; Aguiar and Valentin, 2010). The quantity and quality of foods ingested are associated with the life cycle, prey and predator sizes and the digestion degree (Bowen, 1983).

Changes in diet observed in the 2012-2013 sample and by authors Barbini and Lucifora (2011) may indicate a change in the eating habits of $R$. agassizii due to environmental and anthropogenic factors, therefore, further studies connecting the diet with the area of capture, seasonality, depth, and other factors are required.

Mazzoleni and Schwingel (1999) state that the increase of fisheries for elasmobranchs in Brazil can be a result of increased international demand for meat of Rajidae. This fact can be confirmed, because data from the Information Analysis System for Foreign Trade (ALICEWEB2, 2013) of the Foreign Trade Secretariat show that from January 1997 to September 2013, Brazilian exports to South Korea reached roughly $2,500 \mathrm{t}$ of skates of the Rajidae family classified in two categories: fresh or chilled and frozen (ALICEWEB2, 2013).

The population structure of samples was also different, where the specimens collected in 2012-2013 showed greater TL, while specimens from the 2005-2006 sample had a higher FO and smaller TL.

The diet of the skate $R$. agassizii in both periods analyzed was composed of the same food groups, however in the 2012-2013 period, the main diet group was teleostei fish captured at lower depths (25-70 m). In the 2005-2006 period, the most important group was the decapods, mainly shrimps captured at higher and lower depths (10-146 m). These differences were probably caused by different fishing gears used at different depths and sampling period, besides the biological, ecological, and oceanographic factors.

\section{Acknowledgements}

We give thanks to CAPES for the opportunity and for the scholarship granted. We are also thankful to all my colleagues at the Instituto de Pesca who helped us to collect and sort samples. We give thanks to all the researchers and interns at the Instituto de Pesca that had some collaboration with this article.

\section{References}

AGUIAR, A.A. and VALENTIN, J.L., 2010. Biologia e ecologia alimentar de elasmobrânquios (Chondrichthyes: Elasmobranchii): uma revisão dos métodos e do estado da arte no Brasil. Oecologia 
Australis, vol. 14, no. 2, pp. 464-489. http://dx.doi.org/10.4257/ oeco.2010.1402.09.

ALICEWEB2, 2013 [viewed 9 October 2013]. Sistema de análise das informações de comércio exterior via internet: AliceWeb2 [online]. Available from: http://aliceweb2.mdic.gov.br

BARBINI, S.A. and LUCIFORA, L.O., 2011. Feeding habits of the rio skate, Rioraja gassizi (Chondrichthyes, Rajidae), from off Uruguay and north Argentina. Journal of the Marine Biological Association of the United Kingdom, vol. 91, no. 06, pp. 1175-1184. http://dx.doi.org/10.1017/S0025315410001529.

BOWEN, S.H., 1983. Quantitative description of the diet. In: L.A. NIELSEN and D.L. JOHNSON, eds. Fishery techniques. Maryland: American Fishery Society, pp. 325-336.

BRASIL. Ministério do Meio Ambiente e dos Recursos Naturais Renováveis, 2008. Instrução Normativa $n^{\circ} 189$, de 23 de setembro de 2008. Diário Oficial da República Federativa do Brasil, Brasília, 23 set.

CARPENTER, K.E., 2002. The living marine resources of the Western Central Atlantic. Rome: FAO, vol. 1. 600 p. Special Publication, No. 5.

CORTÉS, E., 1997. A critical review of methods of studying fish feeding based on analysis of stomach contents: application to elasmobranch fishes. Canadian Journal of Fisheries and Aquatic Sciences, vol. 54, no. 3, pp. 726-738. http://dx.doi. org/10.1139/f96-316.

COSTA, R.C., FRANSOZO, A., MELO, G.A.S. and FREIRE, F.A.M., 2003. Chave ilustrada para identificação dos camarões dendrobranchiata do litoral norte do estado de São Paulo, Brasil. Biota Neotropica, vol. 3, no. 1, pp. 1-4. http://dx.doi.org/10.1590/ S1676-06032003000100011.

DOLGOV, A.V., 2005. Feeding and Food Consumption by the Barents Sea Skates. Journal of Northwest Atlantic Fishery Science, vol. 35, pp. 495-503. http://dx.doi.org/10.2960/J.v35.m523.

DULVY, N.K. and REYNOLDS, J.D., 2002. Predicting extinction vulnerability in skates. Conservation Biology, vol. 16, no. 2, pp. 440-450. http://dx.doi.org/10.1046/j.1523-1739.2002.00416.x.

EBERT, D.A. and BIZZARRO, J.J., 2007. Standardized diet compositions and trophic levels of skates (Chondrichthyes, Rajiformes, Rajoidei). Environmental Biology of Fishes, vol. 80, no. 2-3, pp. 221-237. http://dx.doi.org/10.1007/s10641-007-9227-4.

ELLIS, J.R., SILVA J.F., MCCULLY, S.R., EVANS, M. and CATCHPOLE T., 2010. UK fisheries for skates (Rajidae): history and development of the fishery, recent management actions and survivorship of discards. Denmark: International Council for the Exploration of the Sea. 38 p. ICES CM/E:10.

FIGUEIREDO, J.L., 1977. Manual de peixes marinhos do sudeste do Brasil. I Introdução. Cações, raias e quimeras. São Paulo: Museu de Zoologia da Universidade de São Paulo. 104 p. http:// dx.doi.org/10.5962/bhl.title.109986.

FIGUEIREDO, I.L. and MENEZES, N.A., 1978. Manual de peixes marinhos do sudeste do Brasil. II. Teleostei (1). São Paulo: Museu de Zoologia da Universidade de São Paulo. 110 p.

FIGUEIREDO, I.L. and MENEZES, N.A., 1980. Manual de peixes marinhos do sudeste do Brasil. III. Teleostei (2). São Paulo: Museu de Zoologia da Universidade de São Paulo. 90 p.

FRISK, M.G., 2010. Life History Strategies of Batoids. In: J.C. CARRIER, J.A. MUSICK and M.R. HEITHAUS. Sharks and their relatives II: biodiversity, adaptive physiology, and conservation life history strategies of batoids. New York: CRC Press, pp. 283-316.

GAICHAS, S., SAGALKIN, N., GBURSKI, C., STEVENSON, D. and SWANSON, R., 2005. Gulf of Alaska skates. In: NORTH PACIFIC FISHERY MANAGEMENT COUNCIL - NPFMC. Stock assessment and fishery evaluation report for the groundfish resources of the Gulf of Alaska. Anchorage: NPFMC, pp. 881-926.

HOZBOR, N., MASSA, A. and VOOREN, C.M., 2004 [viewed 24 July 2012]. Atlantoraja castelnaui. In: INTERNATIONAL UNION FOR CONSERVATION OF NATURE - IUCN. IUCN Red List of Threatened Species. Version 2012.1 [online]. Available from: www.iucnredlist.org

INTERNATIONAL UNION FOR CONSERVATION OF NATURE - IUCN, 2012 [viewed 24 July 2012]. IUCN Red List of Threatened Species. Version 2012.1 [online]. Available from: www.iucnredlist.org

KYNE, P.M., SAN MARTÍN, J. and STEHMANN, M.F.W., 2007 [viewed 24 July 2012]. Rioraja agassizii. In: INTERNATIONAL UNION FOR CONSERVATION OF NATURE - IUCN. IUCN Red List of Threatened Species. Version 2012.1 [online]. Available from: www.iucnredlist.org

LINK, J.S. and GARRISON, L.P., 2002. Changes in piscivory associated with fishing induced changes to the finfish community on Georges Bank. Fisheries Research, vol. 55, no. 1-3, pp. 71-86. http://dx.doi.org/10.1016/S0165-7836(01)00300-9.

MARION, C., VASKE-JUNIOR, T., GADIG, O.B.F. and MARTINS, I.A., 2011. Feeding habits of the shortnose guitarfish, Zapteryx brevirostris (Müller and Henle, 1841) (Elasmobranchii, Rhinobatidae) in southeastern Brazil. Brazilian Journal of Biology $=$ Revista Brasileira de Biologia, vol. 71, no. 1, pp. 83-89. http:// dx.doi.org/10.1590/S1519-69842011000100013. PMid:21437403.

MASSA, A., HOZBOR, N. and VOOREN, C.M., 2006 [viewed 24 July 2012]. Atlantoraja cyclophora. In: INTERNATIONAL UNION FOR CONSERVATION OF NATURE - IUCN. IUCN Red List of Threatened Species. Version 2012.1 [online]. Available from: www.iucnredlist.org

MAZZOLENI, R.C. and SCHWINGEL, P.R., 1999. Elasmobranch species landed in Itajaí harbor (southern Brazil). Notas Técnicas FACIMAR, vol. 3, pp. 111-119.

MELO, G.A.S., 1996. Manual de identificação dos Brachyura (caranguejos e siris) do litoral brasileiro. São Paulo: Plêiade. 604 p.

MELO, G.A.S., 1999. Manual de identificação dos Crustacea Decapoda do litoral brasileiro. São Paulo: Plêiade. 551 p.

MENEZES, N.A. and FIGUEIREDO, I.L., 1985. Manual de peixes marinhos do sudeste do Brasil. V. Teleostei (4). São Paulo: Museu de Zoologia da Universidade de São Paulo. 105 p.

MUTO, E.Y., SOARES, L.S.H. and GOITEIN, R., 2001. Food resource utilization of the skates Rioraja agassizii (Müller and Henle, 1841) and Psammobatis extenta (Garman, 1913) on the continental shelf off Ubatuba, South-eastern Brazil. Revista Brasileira de Biologia =. Brazilian Journal of Biology $=$ Revista Brasileira de Biologia, vol. 61, no. 2, pp. 217-238. http://dx.doi. org/10.1590/S0034-71082001000200005.

ODDONE, M.C., AMORIM, A.F., MANCINI, P.L., NORBIS, W. and VELASCO, G.A., 2007. The reproductive biology and cycle of Rioraja agassizi (Müller \& Henle, 1841) (Chondrichthyes: Rajidae) in southeast Brazil, SW Atlantic Ocean. Scientia Marina, vol. 71, no. 3, pp. 593-604. http://dx.doi.org/10.3989/ scimar.2007.71n 3593 . 
PÉREZ-FARFANTE, I. and KENSLEY, B., 1997. Penaeoid and sergestoid shrimps and prawns of the world: keys and diagnoses for the families and genera. Los Angeles: University of California. 233 p. Mémoires du Muséum National d'Histoire Naturelle, no. 175.

SAN MARTÍN, J.M., STEHMANN, M.F.W. and KYNE, P.M., 2007 [viewed 24 July 2012]. Atlantoraja platana. In: INTERNATIONAL UNION FOR CONSERVATION OF NATURE - IUCN. IUCN Red List of Threatened Species. Version 2012.1 [online]. Available from: www.iucnredlist.org

SCHWINGEL, P.R. and ASSUNÇÃO, R., 2009. Hábitos alimentares da raia Atlantoraja platana (Günther, 1880) (Elasmobranchii, Rajidae) no litoral norte de Santa Catarina, Brasil. Pan-American Journal of Aquatic Sciences, vol. 4, no. 4, pp. 446-455.

SCHWINGEL, P.R. and CASTELLO, J.P., 1994. Alimentacion de la anchoita (Engraulis anchoita) en el sur de Brasil. Frente Marítimo, vol. 15, pp. 67-85.

SOARES, L.S.,H. and APELBAUM, R., 1994. Atividade alimentar diária da cabrinha Prionotus punctatus (Teleostei: Triglidae) do litoral de Ubatuba, Brasil. Boletim do Instituto Oceanográfico, vol. 42 , no. 1-2, pp. 85-98.
SOARES, L.S.H., VAZZOLER, A.E.A.M. and CORREA, A.R., 1999. Diel feeding chronology of the skate Raja agassizii (Müller and Henle) (Pisces, Elasmobranchii) on the continental shelf off Ubatuba, southeastern Brazil. Revista Brasileira de Zoologia, vol. 16, no. 1, pp. 201-212. http://dx.doi.org/10.1590/S010181751999000100016 .

VIANNA, M., ARFELLI, C.A. and AMORIM, A.F., 2000. Feeding of Mustelus canis (Elasmobranchii, Triakidae) caught off south-southeast coast of Brazil. Boletim do Instituto de Pesca, vol. 26 , pp. 79-84.

VOOREN, C.M. and KLIPPEL, S., 2005. Biologia e status de conservação do cação-listrado Mustelus fasciatus. In: C.M. VOOREN and S. KLIPPEL, eds. Ações para a conservação de tubarões e raias no sul do Brasil. Porto Alegre: Igaré, pp. 83-96.

WETHERBEE, B.M. and CORTÉS, E., 2004. Food consumption and feeding habits. In: J.C. CARRIER, J.A. MUSICK and M.R. HEITHAUS, eds. Biology of sharks and their relatives. Bocca Raton: CRC Press, pp. 225-246.

ZAVALA-CAMIN, L.A. 1996. Introdução aos estudos sobre alimentação natural em peixes. Maringá: EDUEM. 129 p. 